\title{
The Wringin Lawang Concept in the Border Gapura of Malang City through Fractal Geometry Synthesis
}

\author{
Antariksa $^{1}$, Adrian Widisono ${ }^{2}$, Yusfan Adeputera Yusran ${ }^{3 *}$ \\ ${ }^{1,2,3}$ Department of Architecture, Faculty of Engineering, Universitas Brawijaya, Malang, Indonesia \\ *Corresponding author. Email: yusfan@ub.ac.id
}

\begin{abstract}
The era of the Majapahit kingdom was the forerunner of gapura. In those days, the gapura has a function as the entrance to the kingdom. Nowadays, the function of gapura shifted into a marker towards the inclusion of a city, including Malang. The entrance gapura of Malang City is identified with a character similar to one of Majapahit relic temple, Gapura Wringin Lawang, located in Mojokerto, East Java. This study aims to visualize the suitability of geometric characters in the city of Malang with Gapura Wringin Lawang. The pairing of four border gapura with the Gapura Wringin Lawang was analyzed by identifying the physical characteristics of the arch to demonstrate the visual suitability between the entrance gapura in Malang City with Gapura Wringin Lawang. To strengthen the results of the analysis, continued synthesis by using the method of fractal geometry assisted by a box-counting method. This method divides the visual image from visible buildings into squares of varying sizes. This method is used to evaluate the fractal dimensions to find out the suitability between the existing buildings and the initial concept of the design. In the future, this concept can help the designer to interpret the idea as well as widen creativity in designing similar buildings.
\end{abstract} Keywords: Fractal geometry, gapura, box-counting

\section{INTRODUCTION}

Geometry becomes an essential element in architectural design as a tool to define space. Geometry is a rule that facilitates designers in the design process to achieving something desirable to become more organized and beautiful. These rules seem to bind and direct design to a particular purpose. Without any particular rule, the architect would only be stonework that devises stones to become a result without meaning. Conversely, when the designer decides to hold a particular 'rule' that matches his soul and the spirit of his environment (genius loci), then the design can be a meaningful process of producing a meaningful building as well.

Fractal geometry is a natural geometry that has an irregular formation. Natural geometry is not entirely unmeasured. Therefore, the fractal approach is used so that the identification of the irregular form can be measured. In principle, fractals use a way of scaling the formation of each fragment of the formation. The concept of the fractal dimension is to play a certain rule in its use [1]. Fractal geometry in architecture has existed since the classical and modern architectural times because the fractal geometry is a natural geometry that forms very close to humans.

The temple is one example that takes a natural form into its architecture. A loop of natural geometry in the temple that uses the calculation rules of Vastu Purusa Mandala uses repeated geometry of the square with various sizes of large and small to form certain patterns. If observed deeply, this pattern is part of the fractal geometry, so that through the assessment can be developed in architectural design.

Gapura, as one part of the temple [2], is one of the types of buildings that we will first meet when entering a temple/candi. Gapura comes from the Sanskrit language "Gopura," which means gate [3]. Gapura generally a term for the entrance of temples, noble houses, palaces, villages, and countries [4]. Gapura is one of the relics of the Majapahit kingdom that has a Hindu pattern. One of the existing gapura examples is Gapura Wringin Lawang, which still stands since the 14th century, located in Jatipasar Village, Trowulan Sub-district, Mojokerto Regency, East Java province.

Physically, the Gapura Wringin Lawang has a temple-like shape that is perfectly halved so that it has an asymmetrical balance that is found in Java, Bali, and Lombok [5]. In the Majapahit era, the gapura was used as the entrance to the kingdom. It differentiates between the sacred (inside the kingdom) and the profane area (outside the kingdom). It means gapura at that time was not used as a marker alone but also as a differentiator of space zoning. The characteristic of this gapura, which is on the open roof, on the part of the body and legs are not equipped ornamentation but the dominant horizontal line [6].

Nowadays, the gapura is often seen as the boundary marker between cities, especially in the object of study, namely in the city of Malang. There is a shift from the previous function as the entrance to the government area. This study aims to determine the geometric characteristics of the gates of Malang City boundary with Gapura Wringin Lawang through the fractal geometry approach. 
The gate marker of the city is located to the north, west, east, and south of Malang.

In this study, Gapura Wringin Lawang will be further identified using the box-counting method. Furthermore, the gate on the border of Malang City is identified by the same method and then paired to see similarities in proportion. The calculation of geometry in the gapura of Wingin Lawang also uses Vastu Sastra calculations that affect the temple formation. According to Rahadian (2018), the theory of geometry present in the temple using Vastu Sastra and geometric Cartesian-cruciform on the floor plan, while the façade itself is a triangular silhouette as a manifestation of meru (mountain). Facades with a variety of textures in the form of interesting reliefs and ornaments have a comparison of specific ratios that can be reassessed to get the principle of geometry that can be used for future planning.

Similar research titled Fractal Geometry as the synthesis of Hindu cosmology in Kandariya Mahadev temple, Khajuraho by Rian, 2007. This research examines the cosmology of the temple through the geometric fractal approach. The results showed that geometric fractals could read the temple cosmologies. This research was developed to examine the visual equation through the geometric fractal approach, which then can be developed for architectural design.

\section{LITERATURE REVIEW}

\subsection{Gapura as Temple}

Indonesia has a strong architectural tradition and excellence. It is reflected in its architectural form. A diverse and dynamic architectural form is part of the architectural tradition. One of the traces of Indonesian architecture in the era of classical-Hindu-Buddhist Majapahit kingdom that exists to date is a worship building known as temple/candi. The temple buildings are classified into grand design tradition, which presents high style, main culture, power, and good tastes of pattern and designer [7]. Therefore, the temple can be considered as a cultural result of its time.

There are four types of temple based on its architectural typology: tower, stepped, pond/petirtan, and cave [8]. Tower-type is usually candi-shaped like Candi Prambanan, Sewu, and Gedongsongo. This stepped-type is a building arranged in steps, usually constructed on the slopes like Penanggungan, Lawu; the example is Candi Borobudur. Pond/petirtan-type is a building that resembles a pond such as Candi Tikus and Candi Penataran. Cave-type can be associated with ritual or meditation functions such as Selomangleng, Kediri, Elephant Cave, and Sentono Caves. In addition to these types, there are also gate/gapura-type, namely gapura panduraksa/continuous-type and gapura bentar/split-type.

The gapura usually serves as a gate to the kingdom separating the sacred areas (areas in the kingdom) and profane (the area outside the kingdom), such as the Gapura Wringin Lawang. Physically, the verticality of the gapura consists of the head-body-foot or head-torso [9]. Pedestal or leg parts can be square shape, altitude resembling batur, and reached through stairs. The central or body of the temple is generally smaller in dimension, in the form of a cube or cylindrical body. The top or roof of the temple consists of a level arrangement (generally three levels) that shrink upward, ending with a crown.

\subsection{Fractal Geometry in Temple Architecture}

Fractal geometry in architecture can produce beautiful and complex ideas that have strong universal energy reflected in the building. The Hindu temple is the best example of the application of fractal geometry from the past with a cosmic religious view, which existed before the discovery of fractal geometry theory. The fractal geometry is used to manifest or transform Hindu cosmology and physiology into the Vastu Purusha Mandala diagram. Vastu refers to the physical environment. Purusha refers to the cosmic energy or creature, while the Mandala is a diagram or graph [10].

Fractals have self-similar characteristics, which means fractals have the same properties for the various scales used. A fractal dimension is a fractional number that can be used as an imagery feature identifier. The fractal dimensions in the fractal geometry are calculations that measure the value of the fractality of an object [10]. For each fractal of the dimension object, the fractals are always non-integer, i.e., unlike rounded dimensions (dots (zero dimensions), lines (one dimension), square (twodimensional), and cube (three-dimensional)). A fractal object is a fragment of a dimension that means a fractal object can be between one and two dimensions or between two dimensions and three dimensions. It is because between one dimension and two dimensions the fractal ' $D$ ' is always more than one and less than two (i.e., $1<\mathrm{D}<2$ ), whereas objects between two and three dimensions of ' $\mathrm{D}$ ' fractals are always more than two and less than three (i.e., $2<\mathrm{D}<3$ ). So the fractal dimensions are fractional instead of integers.

\subsection{The Calculation Box-Counting Method in Fractals Geometry}

Fractal dimensions can be calculated by the box-counting method. This method divides the image into squares of varying sizes. The Box Counting Method is a method used to evaluate fractal dimensions from visible buildings, mountains, trees, or objects that are not fractals. The fractal dimensions calculated with the box-counting method measure the fractality of an image based on roughness, texture, or the amount of detail of the image. Images that have a fractal dimension of 1.1 to 1.5 show a lack of detail complexity, whereas images that have a fractal dimension of 1.6-1.9 but less than the value of two 
integers, indicating the high complexity of the detail. The roughness of the image that has a fractal dimension of $1.21-1.25$, or the dimensions of 1.81-1.86, is visually not so much differentiated when viewed with the naked eye. In fractals Dimensions 1.1, 1.2, 1.3,.., 1.8 and 1.9 can be visible indifference [10].

According to Rian [10], there are several steps to evaluate the fractals of an image with this method of counting box, namely:

1. A square grid is placed above the image

2. Scale the ' $S$ ' grid on the image

3. Calculate the square grid marked by the image. The number of grids is ' $\mathrm{N}$.'

4. Repeat the process with the same image, just change the scale of the segmented grid

5 . The fractal dimensions can be calculated by changing the results of the ' $\mathrm{S}$ ' and ' $\mathrm{N}$ ' into the log-log graph, the slope of the line generated from the log-log graph 6. Specifying the fractal dimensions of the image
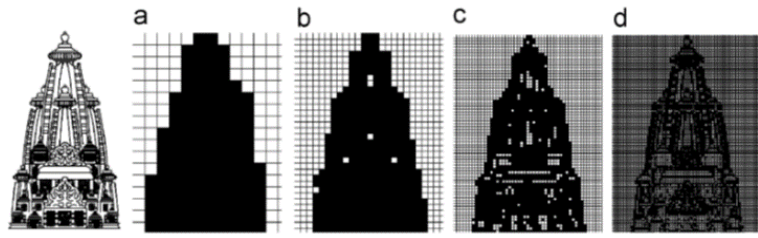

Figure 1 Applying a Counting Box to the leftmost image - fractal images; (a) grid size 24; (b) grid size 12; (c) grid size 6; and (d) grid size 3 [10]

\section{METHOD}

The study used the fractal geometry method to determine the geometric characteristics of the entrance gapura in the north, south, east, and west of Malang City (Figure 2). This study was preceded by field observation on several gapura that became research objects, and also the Gapura Wringin Lawang. The analysis is done related to the physical characteristics of the gapura.

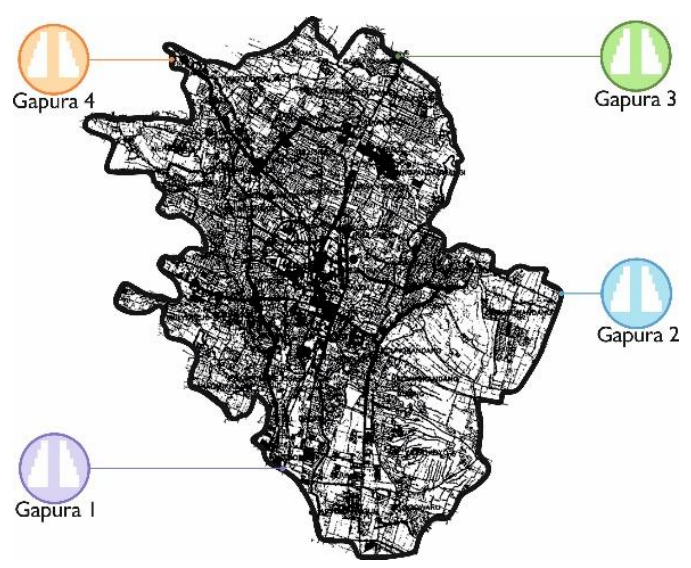

Figure 2 Location of gapuras at the border of Malang City
The results of the identification of these two analyses are then synthesized using a box-counting parameter to determine the geometric suitability in fractals. To facilitate the synthesis of box calculations, this study used the Fractalyse software developed by TheMA to determine the value of fractal dimensions.

\subsection{Data Collection}

The research uses a field observation for the data collection. The observation aims to obtain the dimensions of Gapura Wringin Lawang and four border gapuras of Malang City. The next step is to redraw the gapura to analyze its fractal geometry.

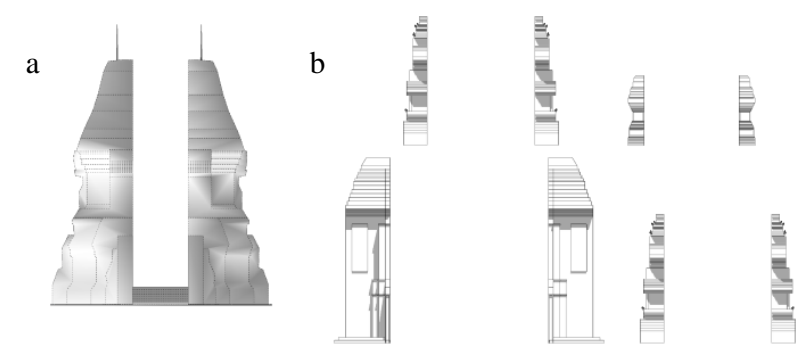

Figure 3 Redrawing of gapura; (a) Gapura Wringin Lawang; (b) gapuras at Malang City border

\subsubsection{Identification object study}

There are four gapuras to be analyzed. The gapuras are located on the north, south, east, and west border of Malang City. The gapuras become the gate of the city border. The following are explanations of the location and dimensions of each gapura.

\subsubsection{Gapura Wringin Lawang}

In 1815, Gapura Wringin Lawang became known and popularized by Raffles in his book "History Of Java I", mentioned with the term "Gapura Jati Pasar". In 1990, this gapura was renovated by the Mojokerto Cultural Reserve and Preservation Hall and was completed in the year 1995. The name Wringin Lawang is from a banyan tree that was high above the gate when it was first discovered (Wringin $=$ Beringin tree - Ficus benjamina), while Lawang means door. Physically, the Gapura Wringin Lawang is measured $13 \times 11.5 \mathrm{~m}$ with a height of $15.5 \mathrm{~m}$. It was built from red bricks; each brick is $6 \times 15 \times 21 \mathrm{~cm}$. The distance between two parts of the gapura is $3.5 \mathrm{~m}$ with the stairs on the east and west side. 


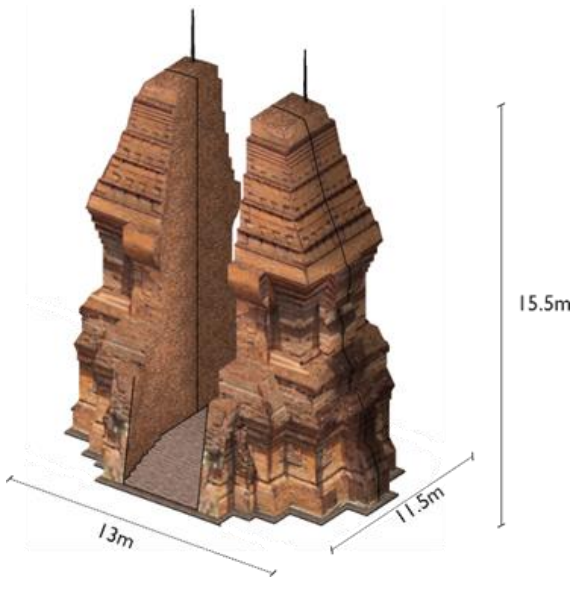

Figure 4 Gapura Wringin Lawang

\subsubsection{Gapura 1}

Gapura 1 is located on the south border of Malang City, on Jalan Nasional, Pakisaji Sub-district, Malang Regency. This gate is a link between Malang City and Pakisaji Subdistrict, Malang Regency. Gapura 1 location is adjacent to the Kebonagung sugar factory. Gapura 1 has a width of $9.80 \mathrm{~m}$ and a height of $8.13 \mathrm{~m}$.

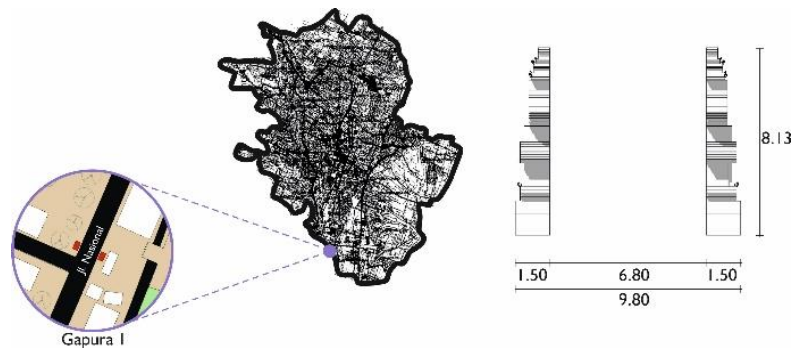

Figure 5 Location and dimension Gapura 1

\subsubsection{Gapura 2}

Gapura 2 is located on the east border of Malang City, on Jalan Raya Kedungrejo, Pakis Sub-district, Malang Regency. This gate is a link between Malang City and Pakisaji Sub-district, Malang. Gapura 2 has a width of $8.00 \mathrm{~m}$ and a height of $4.42 \mathrm{~m}$.
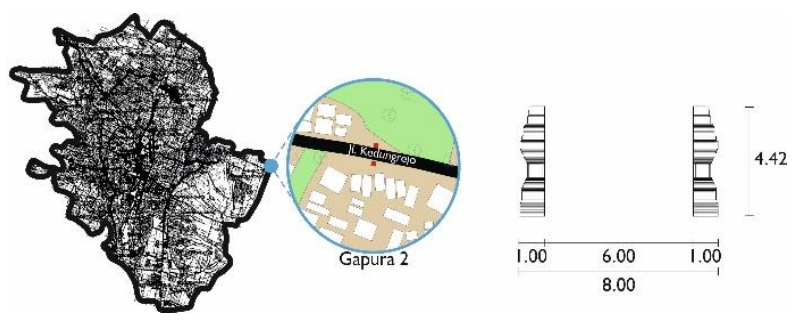

Figure 6 Location and dimension Gapura 2

\subsubsection{Gapura 3}

Gapura 3 is located on the north border of Malang City, on Jalan Raya Malang-Gempol of Balearjosari Subdistrict, District of Blimbing, Malang City. This gate is a link between the Malang City and Singosari District of Malang Regency. Gapura 3 has a width of $17,00 \mathrm{~m}$ and a height of $11.69 \mathrm{~m}$.

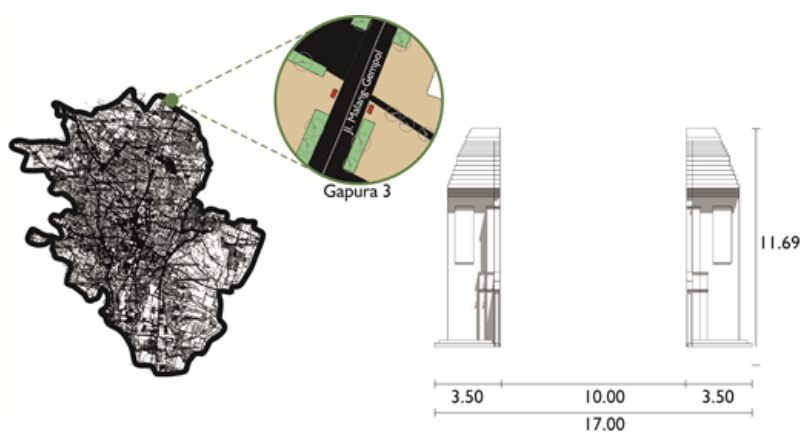

Figure 7 Location and dimension Gapura 3

\subsubsection{Gapura 4}

Gapura 4 is located on the west border of Malang City, on Jalan Raya Tlogomas, Lowokwaru Sub District, Malang City. This gate is a link between Malang City and Jalan Raya Sengkaling to Batu City. Gapura 4 has a dimension width of $9,80 \mathrm{~m}$ and height of 8.13 .
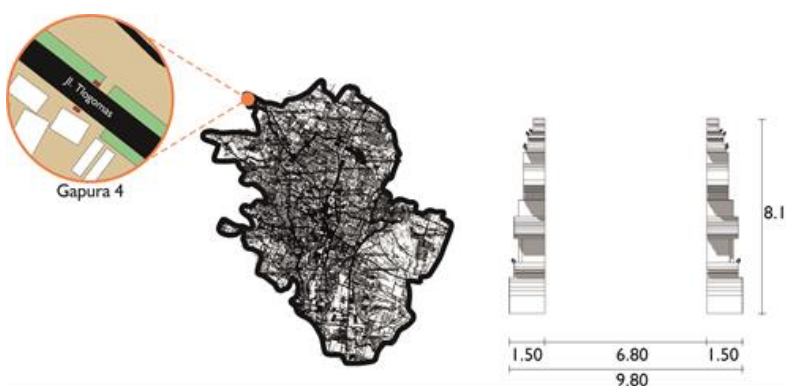

Figure 8 Location and dimension Gapura 4

\subsection{Data Analysis}

In the method of data analysis using box-counting Gapura Wringin Lawang and border gates of Malang City are compared to get the fractal value. The data analysis steps are 1) The redrawing the gapura image is inserted into the Fractyalyse application with the TIFF image format; 2) The analysis is done by box size (linear) of 240, 120, 60, and 30 with a maximum size of 3506 . The entire image is set at 300px resolution; 3) The results of the analysis aim to find out the $\log (\mathrm{S})$ and $\log (\mathrm{N})$ values of the box 240 , 120,60 , and 30 for each gate. Then, the fractal dimension of the linear regression equation of each gapura can be found. 


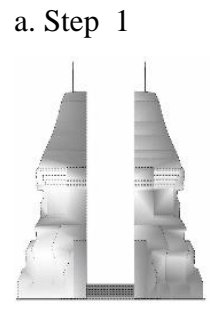

b. Step 2

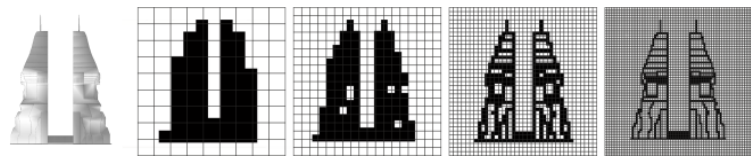

c. Step 3

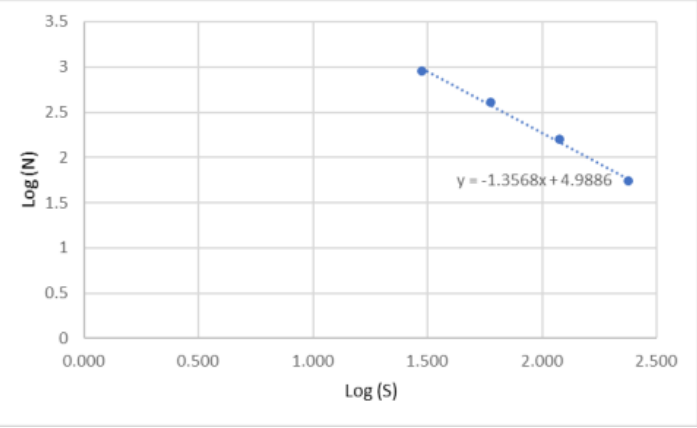

Figure 9 Steps of data analysis; (a) Redrawing the gapura; (b) Analyzing the gapura with grid 240, 120, 60,30 ; (c) Find the results of the fractal dimension.

\section{RESULT AND DISCUSSION}

\subsection{Box Counting Analysis}

In the box-counting analysis, the calculation will analyze each gapura. Gapura to be analyzed is Gapura Wringin Lawang as a reference and four border gapuras in Malang City. All gapuras were analyzed to produce a fractal dimension. Fractal analysis is performed with a box size of 240, 120, 60, and 30 .

\subsubsection{Box-Counting Analysis of Gapura Wringin Lawang}

The gapura that was first analyzed was Gapura Wringin Lawang as a reference. Then it will be compared with other gates. The results of the analysis of fractals with sizes 240, 120, 60, and 30 are presented in Table 1 . a

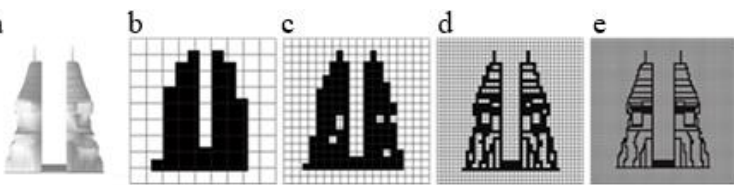

Figure 10 Box-counting of Gapura Wringin Lawang; (a) Elevation of Gapura Wringin Lawang; (b) Box size 240; (c) Box size 120; (d) Box size 60; (e) Box size 30

Table 1. Box-counting analysis of Gapura Wringin Lawang

\begin{tabular}{|c|c|c|c|c|}
\hline Step & $\begin{array}{c}\text { Grid size } \\
\text { (S) }\end{array}$ & $\begin{array}{c}\text { Marked box } \\
(\mathbf{N})\end{array}$ & $\log (\mathbf{S})$ & $\log (\mathbf{N})$ \\
\hline 1 & 240 & 54 & 2.380 & 1.732 \\
\hline 2 & 120 & 156 & 2.079 & 2.193 \\
\hline 3 & 60 & 406 & 1.778 & 2.608 \\
\hline 4 & 30 & 903 & 1.477 & 2.955 \\
\hline
\end{tabular}

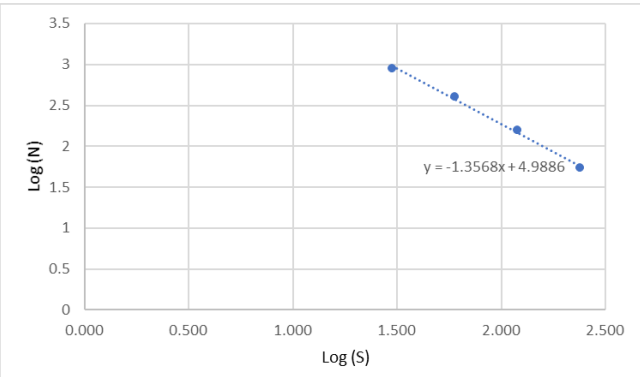

Figure 11 Fractal dimension of Gapura Wringin Lawang $(1,357)$

\subsubsection{Box-Counting Analysis Gapura 1}

Gapura 1 is located on the south border of Malang City. Results of fractal dimension with sizes 240, 120, 60, and 30 are in Table 2. Gapura 1 has a fractals dimension of 1.404 .

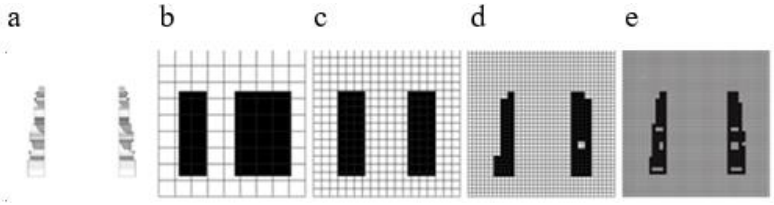

Figure 12. Box-counting of Gapura 1; (a) Elevation of Gapura 1; (b) Box size 240; (c) Box size 120; (d) Box size 60; (e) Box size 30

Table 2. Box-counting analysis of Gapura 1

\begin{tabular}{|l|l|l|l|l|}
\hline Step & $\begin{array}{c}\text { Grid size } \\
(\mathbf{S})\end{array}$ & $\begin{array}{c}\text { Marked box } \\
(\mathbf{N})\end{array}$ & $\log (\mathbf{S})$ & $\log (\mathbf{N})$ \\
\hline 1 & 240 & 9 & 2.380 & 0.954 \\
\hline 2 & 120 & 24 & 2.079 & 1.38 \\
\hline 3 & 60 & 60 & 1.778 & 1.778 \\
\hline 4 & 30 & 170 & 1.477 & 2.23 \\
\hline
\end{tabular}




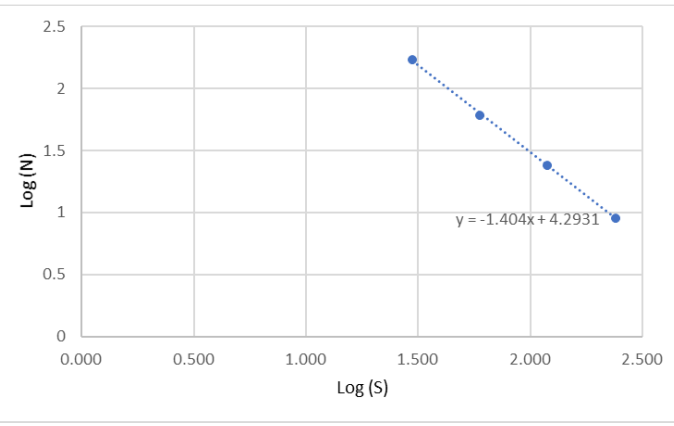

Figure 13 Fractal dimension of Gapura $1(1,404)$

\subsubsection{Box-Counting Analysis Gapura 2}

Gapura 2 is located on the east border of Malang City. Results of fractal values with sizes $240,120,60$, and 30 are in Table 3. Gapura 2 has a fractals dimension of 1.304 .

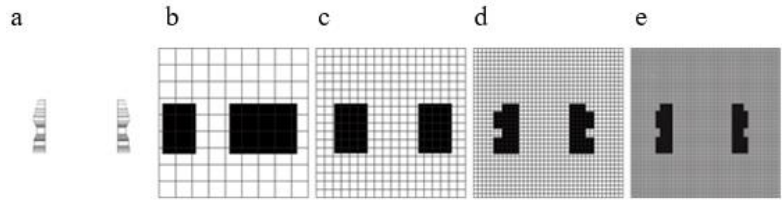

Figure 14 Box-counting of Gapura 2; (a) Elevation of Gapura 2; (b) Box size 240; (c) Box size 120; (d) Box size 60; (e) Box size 30

Table 3 Box-counting analysis of Gapura 2

\begin{tabular}{|l|l|l|l|l|}
\hline Step & $\begin{array}{c}\text { Grid size } \\
(\mathbf{S})\end{array}$ & $\begin{array}{c}\text { Marked box } \\
(\mathbf{N})\end{array}$ & $\log (\mathbf{S})$ & $\log (\mathbf{N})$ \\
\hline 1 & 240 & 6 & 2.380 & 0.778 \\
\hline 2 & 120 & 12 & 2.079 & 1.079 \\
\hline 3 & 60 & 32 & 1.778 & 1.505 \\
\hline 4 & 30 & 88 & 1.477 & 1.944 \\
\hline
\end{tabular}

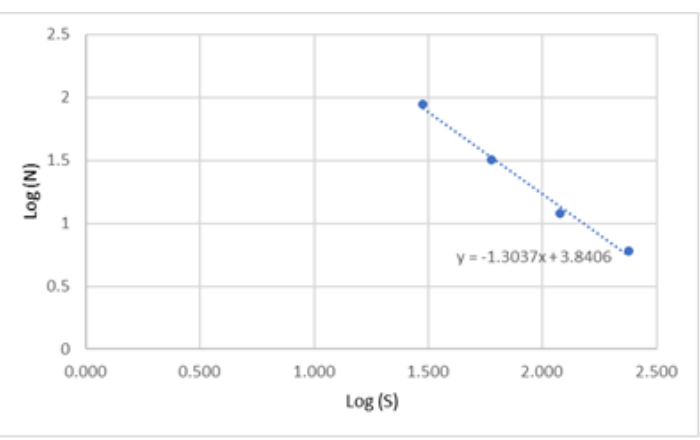

Figure 15 Fractal dimension of Gapura $2(1,304)$

\subsubsection{Box-Counting Analysis of Gapura 3}

Gapura 3 is located on the north border of Malang City. Results of fractal dimension with sizes 240, 120, 60, and
30 are presented in Table 4. Gapura 3 has a fractals dimension of 1.434 .

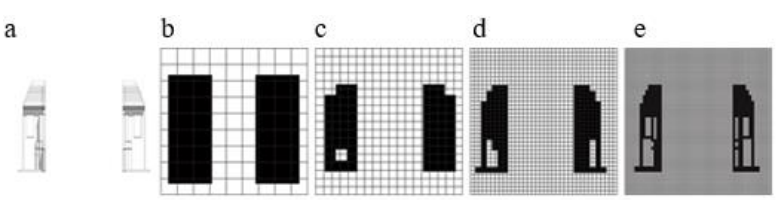

Figure 16 Box-counting of Gapura 3; (a) Elevation of Gapura 3; (b) Box size 240; (c) Box size 120; (d) Box size 60; (e) Box size 30

Table 4 Box-counting analysis of Gapura 3

\begin{tabular}{|l|l|l|l|l|}
\hline Step & $\begin{array}{c}\text { Grid size } \\
(\mathbf{S})\end{array}$ & $\begin{array}{c}\text { Marked box } \\
(\mathbf{N})\end{array}$ & $\log (\mathbf{S})$ & $\log (\mathbf{N})$ \\
\hline 1 & 240 & 20 & 2.380 & 1.301 \\
\hline 2 & 120 & 45 & 2.079 & 1.653 \\
\hline 3 & 60 & 141 & 1.778 & 2.149 \\
\hline 4 & 30 & 375 & 1.477 & 2.574 \\
\hline
\end{tabular}

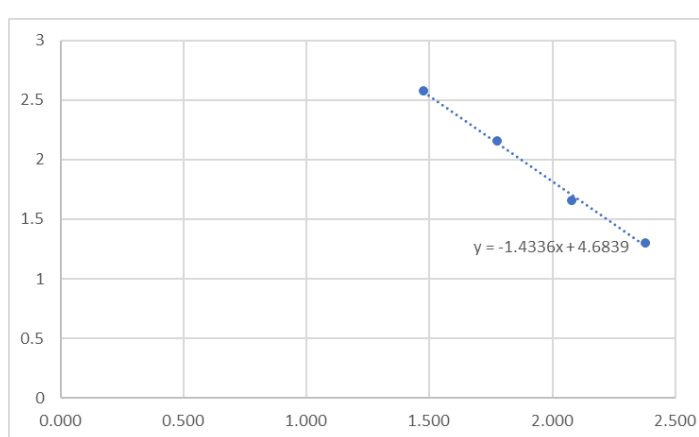

Figure 17 Fractal dimension of Gapura 3 (1.434)

\subsubsection{Box-Counting Analysis of Gapura 4}

Gapura 4 is located on the west border of Malang City. The results of the fractal dimension with sizes 240, 120, 60 , and 30 are presented in Table 5.

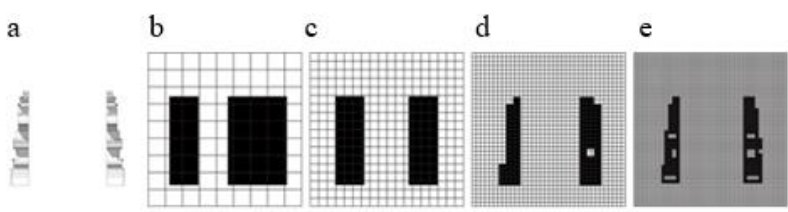

Figure 18. Box-counting of Gapura 4; (a) Elevation of Gapura 4; (b) Box size 240; (c) Box size 120; (d) box size 60; (e) Box size 30

Table 5. Box-counting Analysis Gapura 4

\begin{tabular}{|l|l|l|l|l|}
\hline Step & $\begin{array}{c}\text { Grid size } \\
(\mathbf{S})\end{array}$ & $\begin{array}{c}\text { Marked box } \\
(\mathbf{N})\end{array}$ & $\log (\mathbf{S})$ & $\log (\mathbf{N})$ \\
\hline 1 & 240 & 54 & 2.380 & 1.732 \\
\hline 2 & 120 & 156 & 2.079 & 2.193 \\
\hline 3 & 60 & 406 & 1.778 & 2.608 \\
\hline 4 & 30 & 903 & 1.477 & 2.955 \\
\hline
\end{tabular}




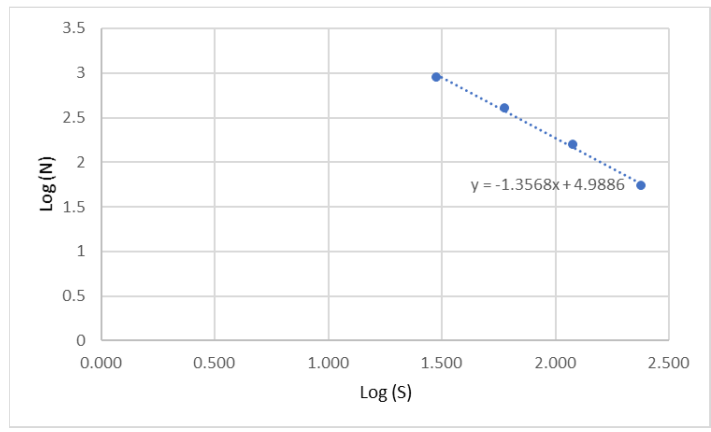

Graph 1. Fractal dimension of Gapura $4(1,304)$

From the analysis, Gapura Wringin Lawang has a fractal dimension of 1.357, Gapura 1 and 4 have a fractal dimension of 1.404, Gapura 2 has a fractal dimension of 1.304. In contrast, Gapura 3 has a fractal dimension of 1.434 .

Table 6. The difference in fractals dimension with Gapura Wringin Lawang

\begin{tabular}{|l|l|l|l|}
\hline No. & \multicolumn{1}{|c|}{ Name of Gapura } & $\begin{array}{c}\text { Fractal } \\
\text { Dimension }\end{array}$ & $\begin{array}{c}\text { Value } \\
\text { Difference }\end{array}$ \\
\hline 1. & Gapura Wringin Lawang & 1,357 & 0 \\
\hline 2. & Gapura 1 & 1,404 & 0,047 \\
\hline 3. & Gapura 2 & 1,304 & 0.053 \\
\hline 4. & Gapura 3 & 1,434 & 0,077 \\
\hline 5. & Gapura 4 & 1,404 & 0,047 \\
\hline
\end{tabular}

Table 6 indicates the highest difference in fractal dimension is between the Gapura Wringin Lawang with Gapura 3, namely 0.077, which is considered not significant. The fractal dimension shows that there is a resemblance between Gapura Wringin Lawang and gapuras in Malang City.

\subsection{Synthesis}

The results show that there is a similarity between the Gapura Wringin Lawang with four gapuras of Malang City. The highest difference in fractal dimension is found between Gapura Wringin Lawang with Gapura 3, but only of 0.077. The fractal value indicates that there is a resemblance of geometry between Gapura Wringin Lawang with four border gapuras in Malang City because the difference in the fractal dimension is not significant.

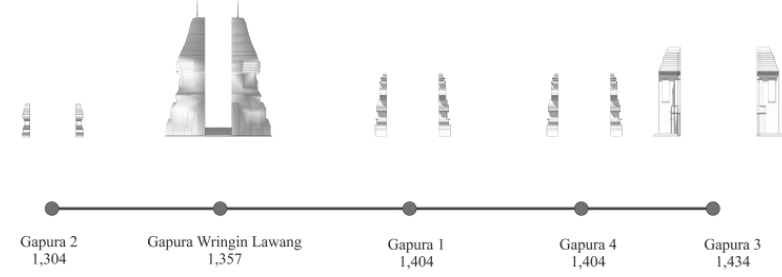

Figure 19. The fractal dimension of the study objects
Figure 15 shows the fractal dimension of all gapuras. Gapura Wringin Lawang (fractal dimension of 1.357) is between Gapura 2 (1.304) and Gapura 1 and 4 (1.404). While Gapura 3 has a fractal dimension of 1.434 with a similarity difference of 0.077 .

\section{CONCLUSION}

Gapura is one of the markers used to enter the borders of a region. The form of a gate that exists today, especially in Malang City, is not separated from its history in terms of geometry. Those gapuras bear a geometric resemblance with Gapura Wringin Lawang in Mojokerto. Geometric similarities are indicated by the fractal value, with the highest difference of only 0.077 between the Gapura Wringin Lawang and Gapura 3, which deemed insignificant. From this study, it can be concluded that Gapura Wringin Lawang is the forerunner of the gapuras in Malang City in terms of its geometry.

\section{ACKNOWLEDGMENT}

This work is supported by the Universitas Brawijaya under 2019 Professorship Funding.

\section{REFERENCES}

[1] B. B. Mandelbrot, The fractal geometry of nature. New York, 1982.

[2] R. Prajudi, Kajian Tipo-Morfologi Arsitektur Candi di Jawa, Institut Teknologi Bandung, 1999.

[3] Suwarna, Tinjauan Selintas Berbagai Jenis Gapura di Daerah Istimewa Yogyakarta, Cakrawala Pendidik., vol. VI (1987) p. 63.

[4] W. Alston, Psychoanalytic Theory and Theistic Belief' in J. Hick (ed.) Faith and the Philosophers. New York: St. Martin's Press, 1964.

[5] Kholisya, Karakteristik Gapura Di Kecamatan Kebakkramat Kabupaten Karanganyar Jawa Tengah (Kajian Sosial Budaya dan Ekonomi), J. Desain vol. 04 No.02 (2017) no. 1957.

[6] W. Yudoseputro, Jejak-Jejak Tradisi Bahasa Rupa Indonesia Lama, Seni Vis., 2008.

[7] A. Rapoport, House Form and Culture, Milwaukee Univ. Winc, 1978.

[8] Prajudi, Eksistensi Candi Sebagai Karya Agung Arsitektur Indonesia di Asia tenggara. D.I Yogyakarta: PT. Kaniskus, 2018. 
[9] T. Prasodjo and V. Degroot, Magical Prambanan. PT (Persero) Taman Wisata Candi Borobudur,

Prambanan \& Ratu Boko, 2013.

[10] Rian, Fractal geometry as the synthesis of Hindu cosmology in Kandariya Mahadev temple, Khajuraho,

Build. Environ., vol. 42, no. 12 (2007) 4093-4107. 